\title{
Correction to: Rain Erosion Maps for Wind Turbines Based on Geographical Locations: A Case Study in Ireland and Britain
}

\author{
K. Pugh ${ }^{1}$ - M. M. Stack
}

Published online: 21 May 2021

(c) The Author(s) 2021

\section{Correction to: \\ Journal of Bio- and Tribo-Corrosion (2021) 7:34 \\ https://doi.org/10.1007/s40735-021-00472-0}

The original article has been corrected. The captions to Figs. 4 and 5 and the second sentence in section 4 were corrected.

Publisher's Note Springer Nature remains neutral with regard to jurisdictional claims in published maps and institutional affiliations.

The original article can be found online at https://doi.org/10.1007/ s40735-021-00472-0.

K. Pugh

kieran.pugh@strath.ac.uk

1 Department of Mechanical Engineering, University of Strathclyde Glasgow, 16 Richmond St, Glasgow G1 1XQ, UK 